\title{
Efficacy of Ozone Gas against Two Stored Product Insects
}

\author{
Ahmed A. Darwish ${ }^{1}$, M. M. Azab ${ }^{1}$, A. E. Abd-El-Aziz ${ }^{2}$ and Eman L. S. Ayad ${ }^{2}$ \\ ${ }^{1}$ Plant Protection Dept., Faculty of Agric., Benha University, Egypt. \\ ${ }^{2}$ Stored Product Pest Dept., Plant Protection Research Institute, A.R.C., Dokki, Giza, Egypt.
}

\begin{abstract}
Efficacy of ozone gas against two of stored product insects, larvae and eggs of almond moth Ephestia cautella (Walker) (Lepidoptera: Pyralidae) and larvae and adults of the saw-toothed grain beetle, Oryzaephilus surinamensis (Coleoptera: Cucujidae) at $30 \pm 1{ }^{\circ} \mathrm{C}$ was tested. The results showed that mortality increased gradually by increasing exposure time of ozone gas. Mortality percent for larvae of E. cautella was $10 \%$ at 0.5 h. exposure and reach to $100 \%$ at $4 \mathrm{hrs}$. after 7day of exposure period. Reduction of egg numbers was $7.65 \%$ at $0.5 \mathrm{hrs}$. exposure period and increased to $81.25 \%$ at $4 \mathrm{hrs}$. These results showed that eggs more tolerant to ozone gas than the larvae. Mortality percent of $O$. surinamensis adults was $5.2 \%$ at $1 \mathrm{~h}$. exposure period and increased to $90.4 \%$ at $4 \mathrm{hrs}$. after 7 days of exposure. Mortality of larvae of $O$. surinamensis was $6.4 \%$ at $0.5 \mathrm{hrs}$. exposure and increased to $92 \%$ at $4 \mathrm{hrs}$. after 7 days of exposure period.
\end{abstract}

Key words: insects, ozone, Ephestia cautella, Oryzaephilus surinamensis

\section{Introduction}

Almond moth, Ephestia cautella is a major world-wide insect pest of stored foods; it occurs in both tropical and temperate regions and it attacks grain, nuts, dried fruits 0061nd great varieties of other stored products. The date crop of Khargeh Oasis suffers annually to a very considerable extent from the ravages of almond moth larvae, feeding on the dates from interior reducing the value of the fruit Gough (1917). This horticultural crop plays a great economic role in the people's life in many communities and larvae of E. cautella attacks fruits either in pre-harvest or in storehouse Abdel -Salam and El-Saeady (1983).

The saw-toothed grain beetle, Oryzaephilus surinamensis (L.) is a common insect pest of stored grain and its products and date fruits in many regions of the world. It is usually found as secondary pest on grain and date fruits damaged by other insects, such as Sitophilus spp. and Ephestia spp.

Semi-dry dates were the most injurious by $E$. calidella, E. cautella and $O$. surinamensis through storage.

Fumigation by methyl bromide is a halogenated compound, ozone depletory and it suspected to be carcinogenic, Taylor (1994). The use of methyl bromide is now being stopped in Egypt since 2015. Fumigation with phosphine is widely used to control stored product pests, has high toxicity and most effective without deleterious effects on the viability of dormant grain. However, the continuous and indiscriminate use of phosphine has resulted in the evolution of resistant populations of targeted pests, Lorini et al. (2007) and Pimentel et al. (2007).

Recently, worldwide attention is focus on screening and developing less hazardous and cheap materials as alternative pest control method.
Graham (1997) reported that ozone has been used for decades in Europe and recently, the Generally Recognized as Safe (GRAS) Status of this gas has been reaffirmed in the United States by the FDA. Moreover, it was in 1997 when the FDA approved ozonation for use in the U.S food processing and fresh produced industries.

Ozone application is currently attracting attention because of its inherent advantages, ozone as a fumigant is reported to kill many of stored-grain insects, Sousa et al. (2008). Also, Fields and White (2002) reported the possible application of ozone in food grain preservation would address the growing concern over the use of harmful pesticides to kill storage pests. Ozone acts as a toxic chemical that can cause anti-oxidative damage of tissues even at low concentrations, Liu et al. (2007).

The objective of this work is to study the efficacy of ozone gas against the larvae, egg of E. cautella and the larvae ,adult of $O$. surinamensis at $30 \pm 1^{\circ} \mathrm{C}$ and $65 \pm 5 \%$ RH.

\section{Materials and Methods}

\section{1- The test insects:}

Almond moth, Ephestia cautella (Lepidoptera: Pyralidae) was reared on artificial diet consists of $250 \mathrm{~g}$ wheat ground, $25 \mathrm{~g}$ sugar ground, $25 \mathrm{~g}$ dry yeast and $37.5 \mathrm{ml}$ glycerol under $27 \pm 1{ }^{\circ} \mathrm{C}$ and $65 \pm 5 \% \mathrm{RH}$ and photoperiod of 12:12 (L: D) El-Badawy et al. (2013). The emerged adults were collected daily and placed in glass cages with screen bottom to obtain eggs. The eggs also collected daily in petri dish and transferred into plastic tubes to obtain new hatched larvae.

The original cultures of saw-toothed grain, Oryzaephilus surinamensis adults and larva were obtained from stored grain pests Department, Plant Protection Research Institute, Egypt. The adults were 
introduced to Frihi date cultivar in glass jars $(1 \mathrm{~kg}$. capacity each). These jars were incubated at $27 \pm 1^{\circ} \mathrm{C}$ and $65 \pm 5 \% \mathrm{RH}$ for two weeks, then the adults were removed and the dates were kept in the jars under the previous conditions till adult emergence.

\section{2 - Production of ozone gas:}

Ozone gas was produced from air using an ozone generator Model OZO 6 VTTL OZO Max Ltd, Shefford, Quebec Canada (OZO Max Ltd, Shefford, Quebec, Canada) from purified extra dry oxygen feed gas at the laboratory of Food Toxicology \& Contaminants, National Research Center, Egypt. The amount of ozone output was controlled by a monitorcontroller having a plug-in sensor on board which is changed for different ranges of ozone concentration and a belt pan in the monitor-controller allows controlling the concentration in a selected range.

3 - Ozone gas application on $\boldsymbol{E}$. cautella larvae:

Small jute bags each jute bag contained $50 \mathrm{~g}$ of artificial diet. Twenty five larvae (25 day old), 100 egg (0-24 hrs. old) of E. cautella and twenty five adult beetle (7-14 days old), twenty five larvae (5 day old) of $O$. surinamensis were added to each jute bag, then closed well and secured with rubber bands.

All bags were exposed inside five glass container (4 liters capacity each) as described by Omar (1983), Zewar and Omar (1991), Ismail et al. (1995) and Omar et al. (1995). Each container consisted of a glass jar with a short neck, closed with rubber stopper with 2 holes; one hole was for the ozone line and the other hole for tubing connected to the ozone destruct unit. Five different exposure times (treatment) of $0.5,1,2,3$ and 4 hours at 300ppm concentration. Three replicates for each treatment. After exposure, treatments were transferred carefully into glass jars $(0.5 \mathrm{~kg}$ capacity each) covered with muslin cloth and secured with rubber bands. Glass jars for each replicate were observed daily for 1, 3, 5, 7 and 10 successive days to count numbers of alive larvae of E. cautella and larvae of $O$. surinamensis but in case of $O$. surinamensis beetle glass jars for each replicate were observed daily for $1,3,5,7,10$ and 12 successive days to count numbers of alive larvae and adult then, calculate mortality percent corrected by Abbott's formula (1925). Untreated (control) treatment is conduct as previously mentioned, but without ozone exposure. While in case of E. cautella egg after 35 day, jars were examined daily to record moth emergence until the emergence of moth stopped. Mortality was estimated as reduction rate in the progeny according the following equation.

Inhibition $(\%)=[($ No of emerged adults in control - No. of emerged adults in treatment) / No. of emerged adults in control] $\times 100$

\section{4 - Statistical analysis of the obtained data:}

The average percent mortality of the tested insect was calculated and corrected using Abbott's formula Abbott (1925). The corrected percentages of mortalities were statistically computed according to the method of Finney (1971). Computed percentage of mortality was plotted versus the corresponding concentrations using LDP line software program to obtain the toxicity regression lines. The lethal times $\mathrm{LT}_{50}$ and $\mathrm{LT}_{90}$ were determined.

\section{Results And Discussion}

\section{1- Effect of ozone gas on Ephestia cautella: 1-1- Larvae:}

Table (1) shows the efficacy of ozone gas at 300 ppm against the larvae of E. cautella at $30 \pm 1^{\circ} \mathrm{C}$ and $65 \pm 5 \%$ RH. Data revealed that the corrected percent mortalities increased gradually by increasing the exposure time as well as the period after treatment. The results cleared that mortality of larvae was $10.4 \%$ at $0.5 \mathrm{~h}$ exposure period after 1 days post treatment and the mortality increased after 10 days post treatment to $49.2 \%$, while the mortality after 4 hrs exposure period was $36 \%$ and the mortality increased after 7 days post treatment to $100 \%$.

Table 1. The efficacy of 300ppm ozone gas against $E$. cautella larvae at $30 \pm 1{ }^{\circ} \mathrm{C} ; 65 \pm 5 \% \mathrm{RH}$.

\begin{tabular}{cccccc}
\hline \multirow{2}{*}{$\begin{array}{c}\text { Exposure time } \\
\text { (hours) }\end{array}$} & \multicolumn{5}{c}{ Mortality \% after indicated days } \\
\cline { 2 - 6 } & $\mathbf{1}$ & $\mathbf{3}$ & $\mathbf{5}$ & $\mathbf{7}$ & $\mathbf{1 0}$ \\
\hline $\mathbf{0 . 5}$ & $\mathbf{1 0 . 4} \pm \mathbf{0 . 3 2}$ & $\mathbf{1 7 . 2} \pm \mathbf{0 . 3 2}$ & $\mathbf{2 4 . 0} \pm \mathbf{0 . 5 7}$ & $\mathbf{3 2 . 0} \pm \mathbf{0 . 5 7}$ & $\mathbf{4 9 . 2} \pm \mathbf{0 . 3 2}$ \\
1 & $\mathbf{1 8 . 4 \pm 0 . 3 2}$ & $\mathbf{3 0 . 4} \pm \mathbf{0 . 3 2}$ & $\mathbf{4 0 . 0} \pm \mathbf{0 . 5 7}$ & $\mathbf{5 3 . 3} \pm \mathbf{0 . 8 7}$ & $\mathbf{6 5 . 2} \pm \mathbf{0 . 3 2}$ \\
2 & $\mathbf{2 4 . 0} \pm \mathbf{0 . 5 7}$ & $\mathbf{4 4 . 0} \pm \mathbf{0 . 5 7}$ & $\mathbf{5 8 . 4} \pm \mathbf{0 . 8 7}$ & $\mathbf{7 4 . 4} \pm \mathbf{0 . 3 2}$ & $\mathbf{8 1 . 2} \pm \mathbf{0 . 8 7}$ \\
3 & $\mathbf{2 9 . 3} \pm \mathbf{0 . 3 2}$ & $\mathbf{4 8 . 0} \pm \mathbf{0 . 0 0}$ & $\mathbf{6 4 . 0} \pm \mathbf{0 . 5 7}$ & $\mathbf{8 2 . 6 4} \pm \mathbf{1 . 2}$ & $\mathbf{9 0 . 4} \pm \mathbf{0 . 6 6}$ \\
4 & $\mathbf{3 6 . 0} \pm \mathbf{0 . 5 7}$ & $\mathbf{5 4 . 6 4} \pm \mathbf{0 . 3 2}$ & $\mathbf{7 4 . 4 \pm 0 . 6 6}$ & $\mathbf{1 0 0 . 0} \pm \mathbf{0 . 0}$ & $\mathbf{1 0 0 . 0} \pm \mathbf{0 . 0}$ \\
\hline
\end{tabular}

Eggs:

Table (2) shows the efficacy of ozone gas at $300 \mathrm{ppm}$ against the egg of E. cautella at $30 \pm 1^{\circ} \mathrm{C}$ and $65 \pm 5 \%$ RH. Obtained data showed that the reduction rate in number of emerged adults was $7.65 \%$ at $0.5 \mathrm{~h}$. exposure periods and increased to
$81.25 \%$ at 4 hrs. exposure period. It was noticed that the percent of emerged moth produced from each stage decreased with increasing the exposure period of ozone. These results show that egg was more tolerant to ozone gas than the larvae. 
Table 2. The efficacy of 300ppm ozone gas against E. cautella eggs at $30 \pm 1^{\circ} \mathrm{C}$ and $65 \pm 5 \% \mathrm{RH}$.

\begin{tabular}{ccccccc}
\hline \multirow{2}{*}{$\begin{array}{c}\text { Exposure time } \\
\text { (hours) }\end{array}$} & \multicolumn{5}{c}{$\begin{array}{c}\text { No. of emerged moths } \\
\text { after indicated days }\end{array}$} & \multirow{2}{*}{ Reduction $(\%)$} \\
\cline { 2 - 5 } & 35 & 38 & 40 & 47 & 55 & \\
\hline 0.5 & 4.000 & 12.00 & 26.33 & 39.66 & 44.33 & 7.650 \\
1 & 3.000 & 8.660 & 23.66 & 35.66 & 37.66 & 21.54 \\
2 & 2.330 & $\mathbf{8 . 0 0 0}$ & 18.66 & 24.66 & 27.66 & 42.38 \\
3 & 2.330 & 5.000 & 10.33 & 14.00 & 16.00 & 66.67 \\
4 & 1.000 & 3.660 & 6.660 & 7.660 & 9.000 & 81.25 \\
\hline Control & 4.330 & 13.66 & 29.00 & 43.00 & 48.00 & \\
\hline
\end{tabular}

Lethal time values and parameters of mortality of larvae of E. cautella exposed to ozone $300 \mathrm{ppm}$ at $30^{\circ} \mathrm{C}$ are presented in Table (3). Results showed that the $\mathrm{LT}_{50}$ for the larvae was 14.30 day at $0.5 \mathrm{~h}$ exposure periods and 1.96 day at $4 \mathrm{hrs}$ exposure periods. The findings of $\mathrm{LT}_{90}$ were 99.14 and 17.02 day respectively.

Table 3. Lethal time values and confidence limits for the larva of E. cautella at various exposure periods of ozone.

\begin{tabular}{|c|c|c|c|c|c|c|c|c|}
\hline \multirow[b]{3}{*}{$\begin{array}{c}\text { Exposure } \\
\text { time } \\
\text { (hours) }\end{array}$} & \multirow[b]{3}{*}{$\begin{array}{l}\mathbf{L T}_{\mathbf{5 0}} \\
\text { (day) }\end{array}$} & \multirow[b]{3}{*}{$\begin{array}{l}\mathbf{L T}_{90} \\
\text { (day) }\end{array}$} & \multicolumn{4}{|c|}{ Confidence limits } & \multirow[b]{3}{*}{ Slope \pm SD } & \multirow[b]{3}{*}{$\mathbf{R}$} \\
\hline & & & \multicolumn{2}{|c|}{$\mathbf{L T}_{\mathbf{5 0}}$} & \multicolumn{2}{|c|}{ LT $_{90}$} & & \\
\hline & & & lower & upper & lower & upper & & \\
\hline 0.5 & 14.30 & 99.14 & 7.09 & 29.08 & 48.96 & 200.73 & $1.52 \pm 0.65$ & 0.999 \\
\hline 1 & 6.91 & 89.56 & 3.35 & 14.25 & 43.45 & 184.58 & $1.15 \pm 0.86$ & 0.971 \\
\hline 2 & 3.24 & 24.59 & 1.81 & 5.81 & 13.74 & 44.01 & $1.46 \pm 0.68$ & 0.972 \\
\hline 3 & 2.48 & 14.44 & 1.47 & 4.20 & 8.55 & 24.37 & $1.68 \pm 0.59$ & 0.951 \\
\hline 4 & 1.96 & 17.02 & 0.90 & 4.28 & 7.82 & 37.67 & $1.37 \pm 0.72$ & 0.903 \\
\hline
\end{tabular}

Lethal time values and parameters of mortality regression line for the eggs of E. cautella exposed to ozone gas .Results showed that the $\mathrm{LT}_{50}$ and $\mathrm{LT}_{90}$ were 2.08 and $6.42 \mathrm{hrs}$, respectively. The results showed clearly that the eggs were tolerant than larvae.

2-Effect of ozone gas on Oryzaephilus surinamensis: 2-1- Adult:
Table (4) shows the efficacy of ozone gas at $300 \mathrm{ppm}$ against the adults of $O$. surinamensis at $30 \pm 1^{\circ} \mathrm{C}$ and $65 \pm 5 \% \mathrm{RH}$. The results showed that adult mortality was $5.2 \%$ at $1 \mathrm{~h}$ exposure periods after 1 days post treatment and the mortality increased after 12 days post treatment to $36 \%$, while that adult mortality was $30.4 \%$ at $4 \mathrm{hrs}$ exposure periods and the mortality increased after 12 days post treatment to $90.4 \%$

Table 4. The efficacy of $300 \mathrm{ppm}$ ozone gas against $O$. surinamensis adults at $30{ }^{\circ} \mathrm{C}$ and $65 \pm 5 \% \mathrm{RH}$.

\begin{tabular}{|c|c|c|c|c|c|}
\hline \multirow{2}{*}{$\begin{array}{c}\text { Exposure time } \\
\text { (hours) }\end{array}$} & \multicolumn{5}{|c|}{ Mortalitay \% after indicated days } \\
\hline & 1 & 3 & 5 & 7 & 12 \\
\hline 0.5 & $\mathbf{0}$ & $\mathbf{0}$ & $6.64 \pm 0.32$ & $8 \pm 0.57$ & $12 \pm 00$ \\
\hline 1 & $5.2 \pm 0.32$ & $9.2 \pm 0.32$ & $12 \pm 0.57$ & $16 \pm 0.57$ & $36 \pm 0.57$ \\
\hline 2 & $10.4 \pm 0.32$ & $\mathbf{1 7 . 2 \pm 0 . 8 7}$ & $22.4 \pm 0.66$ & $30.4 \pm 0.32$ & $56 \pm 0.57$ \\
\hline 3 & $21.2 \pm 0.32$ & $34.4 \pm 0.87$ & $45.2 \pm 0.32$ & $58.4 \pm 0.32$ & $76 \pm 0.57$ \\
\hline 4 & $30.4 \pm 0.32$ & $46.4 \pm 1.2$ & $65.2 \pm 0.32$ & $84 \pm 0.57$ & $90.4 \pm 0.32$ \\
\hline
\end{tabular}

2-2- Larvae:

Table (5) shows the efficacy of ozone gas at $300 \mathrm{ppm}$ against the larvae of $O$. surinamensis at $30 \pm 1^{\circ} \mathrm{C}$ and $65 \pm 5 \% \mathrm{RH}$. The resulted of larvae mortality was $6.4 \%$ at $0.5 \mathrm{~h}$ exposure periods and increased to $38.4 \%$ after 10 days post treatment but at $4 \mathrm{hrs}$ exposure periods was $33.2 \%$ and increased to $92 \%$ after 10 days post treatment. 
Table 5. The efficacy of $300 \mathrm{ppm}$ ozone gas against $O$. surinamensis larvae at $30^{\circ} \mathrm{C}$ and $65 \pm 5 \% \mathrm{RH}$.

\begin{tabular}{|c|c|c|c|c|c|}
\hline \multirow{2}{*}{$\begin{array}{c}\text { Exposure time } \\
\text { (hours) }\end{array}$} & \multicolumn{5}{|c|}{ Mortality \% after indicated days } \\
\hline & 1 & 3 & 5 & 7 & 10 \\
\hline 0.5 & $6.4 \pm 0.320$ & $10.6 \pm 0.32$ & $16 \pm 0.570$ & $24 \pm 0.570$ & $38.4 \pm 0.32$ \\
\hline 1 & $14.4 \pm 0.32$ & $26.4 \pm 0.32$ & $34.4 \pm 0.32$ & $45.2 \pm 0.32$ & $58.4 \pm 0.66$ \\
\hline 2 & $22.4 \pm 0.32$ & $38.4 \pm 0.32$ & $53.2 \pm 0.32$ & $65.2 \pm 0.32$ & $73.2 \pm 0.87$ \\
\hline 3 & $28 \pm 0.570$ & $42.4 \pm 0.32$ & $62.4 \pm 0.32$ & $76.0 \pm 0.00$ & $82.4 \pm 0.32$ \\
\hline 4 & $33.2 \pm 0.32$ & $50.4 \pm 0.32$ & $68 \pm 0.570$ & $85.2 \pm 0.32$ & $92 \pm 0.570$ \\
\hline
\end{tabular}

Table (6) shows lethal time values and parameters of mortality regression line for the adults of $O$. surinamensis exposed to ozone gas. The presented results showed that the $\mathrm{LT}_{50}$ for the adult were 22.27 and 2.43 day at 1 and 4 hrs, respectively. While $\mathrm{LT}_{90}$ values were 108.20 and 14.18 day at 1 and $4 \mathrm{hrs}$, respectively.

Table 6. Lethal time values and confidence limits for the adult of $O$. surinamensis at various exposure periods of ozone.

\begin{tabular}{|c|c|c|c|c|c|c|c|c|}
\hline \multirow{3}{*}{$\begin{array}{c}\text { Exposure } \\
\text { time } \\
\text { (hours) }\end{array}$} & \multirow{3}{*}{$\begin{array}{r}\mathbf{L T}_{50} \\
\text { (day) }\end{array}$} & \multirow{3}{*}{$\begin{array}{l}\mathbf{L T}_{90} \\
\text { (day) }\end{array}$} & \multicolumn{4}{|c|}{ Confidence limits } & \multirow{3}{*}{ Slope \pm SD } & \multirow{3}{*}{$\mathbf{R}$} \\
\hline & & & \multicolumn{2}{|c|}{$\mathbf{L T}_{50}$} & \multicolumn{2}{|c|}{$\mathbf{L T}_{90}$} & & \\
\hline & & & lower & upper & lower & upper & & \\
\hline 1 & 22.27 & 108.20 & 11.75 & 42.18 & 57.12 & 204.94 & $1.86 \pm 0.535$ & 0.987 \\
\hline 2 & 12.62 & 74.38 & 7.09 & 22.46 & 41.79 & 132.40 & $1.67 \pm 0.598$ & 0.957 \\
\hline 3 & 4.95 & 47.52 & 2.61 & 9.36 & 25.12 & 89.89 & $1.31 \pm 0.762$ & 0.958 \\
\hline 4 & 2.43 & 14.18 & 1.44 & 4.11 & 8.39 & 23.95 & $1.68 \pm 0.593$ & 0.935 \\
\hline
\end{tabular}

In Table (7) the presented results showed that the $\mathrm{LT}_{50}$ values of $O$. surinamensis larvae were 21.39 and 2.18 day at 0.5 and 4 hrs, respectively, while
$\mathrm{LT}_{90}$ values were 146.47 and 12.65 day at 0.5 and 4 hrs, respectively. The results showed clearly that the adults were the most tolerant than larvae.

Table 7. Lethal time values and confidence limits for the larva $O$. surinamensis at various exposure periods of ozone.

\begin{tabular}{|c|c|c|c|c|c|c|c|c|}
\hline \multirow{3}{*}{$\begin{array}{c}\text { Exposure } \\
\text { time } \\
\text { (hours) }\end{array}$} & \multirow{3}{*}{$\begin{array}{l}\mathbf{L T}_{50} \\
\text { (day) }\end{array}$} & \multirow{3}{*}{$\begin{array}{l}\text { LT90 } \\
\text { (day) }\end{array}$} & \multicolumn{4}{|c|}{ Confidence limits } & \multirow[b]{3}{*}{ Slope \pm SD } & \multirow[b]{3}{*}{$\mathbf{R}$} \\
\hline & & & \multicolumn{2}{|c|}{$\mathbf{L T}_{50}$} & \multicolumn{2}{|c|}{ LT90 } & & \\
\hline & & & Lower & Upper & Lower & upper & & \\
\hline 0.5 & 21.39 & 146.47 & 10.22 & 44.76 & 70.00 & 306.49 & $1.53 \pm 0.65$ & 0.991 \\
\hline 1 & 9.77 & 135.56 & 4.59 & 20.77 & 63.76 & 288.23 & $1.12 \pm 0.89$ & 0.915 \\
\hline 2 & 4.25 & 43.99 & 2.20 & 8.22 & 22.75 & 85.05 & $1.26 \pm 0.79$ & 0.977 \\
\hline 3 & 2.93 & 23.65 & 1.61 & 5.35 & 12.98 & 43.08 & $1.68 \pm 0.59$ & 0.943 \\
\hline 4 & 2.18 & 12.65 & 1.28 & 3.70 & 7.44 & 21.48 & $1.68 \pm 0.59$ & 0.943 \\
\hline
\end{tabular}

The obtained results are in agreement with those of Osman (2009) who studied the effect of ozone on E. kuehniella at $1 \mathrm{~g} .5 \mathrm{~h} / \mathrm{m}^{3}$ for different exposure periods of $0.5,1,2,3,4$ and $5 \mathrm{hrs}$. He found that larvae required not less than 6 days after ozone exposure to reveal the full effect in the mortality rate. Also, Isikber and Oztekin (2009) mentioned that E. kuehniella is more susceptible to gaseous ozone than larvae of Tribolium confusum. Abo-El-Saad et al. ( 2011) showed that ozonation with $2.0 \mathrm{ppm}$ ozone generated with various time 4,8 and 12 hrs gave 28,73 and $83 \%$ mortality against $E$. cautella adults, while it gave 10, 20 and $27 \%$ mortality in case of larvae, respectively. Lu et al. (2009) observed that effect of this gas on respiration had two distinct phases, a lower respiration of the tested adult and increased the respiration of Sitophilus oryzae, Rhyzopertha dominica and $T$. castaneum adults when ozone degraded to oxygen. Hansen et al. (2012) reported that the freely exposed stages of the eleven species from insect species and mainly adult insects for ozone gas, full control can generally be obtained with $35 \mathrm{ppm}$ for 6 days. However, for control of internal stages of Sitophilus spp. and $R$. dominica, full mortality requires approximately 135 ppm for 8 days. Hussain (2014) found that the mortalities increased gradually by increasing each of exposure time to ozone gas and period after treatment. Mortality percent was $2.76 \%$ at $1 \mathrm{~h}$. exposure, followed significant by $48.60,83.67$ and $97.22 \%$ at 2, 3, $4 \mathrm{hrs}$, respectively. and reach $100 \%$ at 5 hrs. exposure periods after 24 hours, as 
regard to 7 days after exposure to ozone gas, the data noticed that the mortality percent was $38.92 \%$ at 1 hour exposure, followed significantly by 66.55 , $88.37,98.55$ and $100 \%$ at 2, 3, 4 and 5 hrs. exposure periods, respectively.

\section{References}

Abbott, W. S. (1925). A method of computing the effectiveness of insecticide. J. Econ. Entomol. 18: 265- 267.

Abdel-Salam, A. L. and El-Saeady, A. A. (1983). Ecological studies on Ephestia calidella (Guen) and E. cautella (Walker) as date insect pests at Baharia Oases. Proceedings of the first Symposium on Date Palm in Saudi Arabia, March 23-25: 314- 320.

Abo-el-saad, M. M.; Elshafie, H. A.; Al -Ajlan, A. M. and Bou-khowh, I. A. (2011). Non-chemical alternatives to methyl bromide against Ephestia cautella (Lepidoptera: Pyralidae) microwave and ozone. Agric. Biol. J. N. Am., 2(8): 1222- 1231.

El-badawy, S. S; Nasr, E. H and Hussain, H. B. H. (2013). Effect of gamma radiation on Ephestia cautella and some chemical compositions of shelled peanut. Bull. Ent. Egypt, Ser., 39, 193203.

Finney, D.J. (1971): Probit analysis $3^{\text {rd }}$ ed .Cambridge Univ. press, Cambridge, England., PP 333.

Fields, P. G. and White, N. D. G. (2002). Alternatives to methyl bromide treatments for stored-product and quarantine insects. Annual Rev. Entomol. 47: 331- 359.

Gough, L. H. (1917). Notes on an Ephestia, an insect injurios to stored dates in Khargeh Oasis. Bull. Soc. Ent. D,Egypt, 133-140.

Graham, D. (1997). Use of ozone for food processing. Food Technology, 51: 72-73.

Hansen, S. L.; Hansen, P. and Jensena, K. V. (2012). Lethal doses of ozone for control of all stages of internal and external feeders in stored products. (wileyonlinelibrary.com)

Hussain, B. H. (2014). Biological aspects and control of Ephestia cautella (walk) (Lepidoptera:phycitidae) in stored dates. Bull. Ent. Soc. Egypt,91:(187-198).

Isikber, A. A. and Oztekin, S. (2009). Comparison of susceptibility of two stored-product insects, Ephestia kuehniella Zeller and Tribolium confusum du Val to gaseous ozone. J. Stored Prod. Res. 45: 159- 164.

Ismail. I. I.; Omar, E. E. and Hashem, M.Y. (1995). The effect of sublethal concentrations of carbon dioxide $\left(\mathrm{CO}_{2}\right)$ in atmosphere on some biological aspects of the cowpea weevil Callosobrruchus maculates F. (Bruchidae: Coleoptera). Egypt. J. Agric. Res., 73 (1) 111 117.

Liu, H. H.; Wu, Y.C. and Chen, H. L. (2007). Production of ozone and reactive oxygen species after welding. Arch. Environ. Contam. and Toxicol., 53: 513-518.

Lorini, I.; CollinS, P. J.; Daglish, G. J.; Nayak, M. K. and Pavic, H. (2007). Detection and characterization of strong resistance to phosphine in Brazilian Rhyzopertha dominica (F.) (Coleoptera: Bostrychidae). Pest. Manag. Sci. 63:358-364.

Lu, B.; Ren, Y.; Du, Y.; Fu, Y. and GU, J. (2009). Effect of ozone on respiration of adult Sitophilus oryzae (L.) Tribolium castaneum (Herbst) and Rhyzopertha dominica (F.). J. of insect physiology, 55: 885-889.

Omar, E. E. (1983). Studies of the storage of grains in inert atmosphere. Unpublished $\mathrm{Ph}$ D.Thesis, Cairo Univ. Giza. 109 pp

Omar, E. E.; Hashem, M.Y. and Ismail, I.I. (1995) .Effect of carbon dioxide in air on different stages of the rice weevil Sitophilus oryzae (L.) ( Curculionidae : Coleoptera). Egypt. J. Agric. Res., 73 (1) 119-125.

Osman, M. A. M. (2009). Susceptibility of some stored product insects to gaseous ozone treatment under laboratory conditions. Bull. Ent. Soc. Egypt, Econ. Ser., 35: 157- 170.

Pimentel, M.A.G.; Faroni, L.R.D.A.; Totola, M. R. and Guedes, R. N. C. (2007). Phosphine resistance, respiration rate and fitness consequences in stored product insects. Pest. Manag. Sci. 63:876-881.

Sousa, A. H; Faroni, L. R. D.; Guedes, R. N. C.; Totola, M. R. and Urruchi, W. I. (2008). Ozone as a management alternative against phosphine-resistant insect pests of stored products. J. Stored Prod. Res., 44(4): 379-385.

Taylor, R. O. D. (1994). Methyl Bromide is there any future for this notworthy fumigant? J. Stored Prod. Res., 30: 253-260.

Zewar, M. M. and Omar, E. E. (1991). Toxicity of carbon dioxide and methyl bromide as gaseous fumicant mixtures. Egypt. J. Agric. Res., 69 (1) 109- 116. 
فاعلية غاز الأوزون ضد حشرتين من حشرات المواد المخزونه

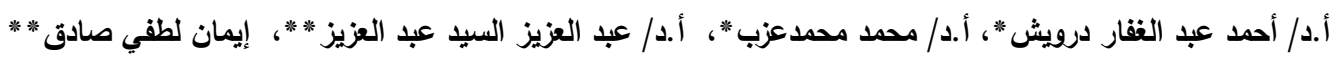

$$
\text { * قسم وقاية النبات- كلية الزراعة - جامعة بنها - مصر }
$$

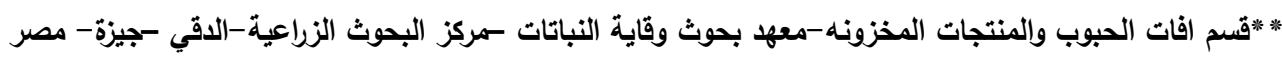

تهذف هذه الداسه الي تقيم فاعلية غاز الأوزون بتركيز

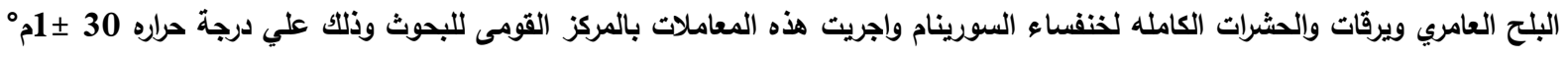

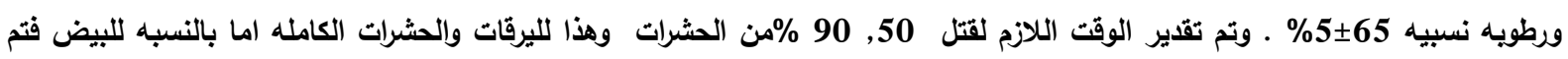

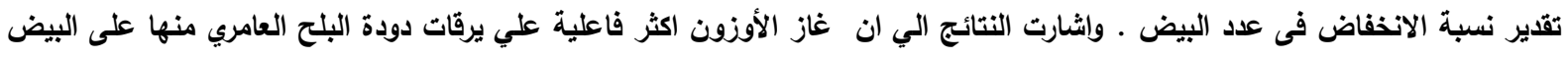

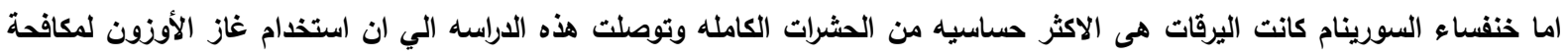
دودة البلح العامري وخنفساء السورينام في المواد المخزونه هي طريقه فعاله وآمنه. 